\title{
Inducible Genetic Suppression of Neuronal Excitability
}

\author{
David C. Johns, ${ }^{1}$ Ruth Marx, ${ }^{2}$ Richard E. Mains, ${ }^{2}$ Brian O’Rourke, ${ }^{1}$ and Eduardo Marbán' ${ }^{1}$ \\ ${ }^{1}$ Section of Molecular and Cellular Cardiology, Division of Cardiology, and ${ }^{2}$ Department of Neuroscience, Johns Hopkins \\ University School of Medicine, Baltimore, Maryland 21205
}

Graded, reversible suppression of neuronal excitability represents a logical goal of therapy for epilepsy and intractable pain. To achieve such suppression, we have developed the means to transfer "electrical silencing" genes into neurons with sensitive control of transgene expression. An ecdysone-inducible promoter drives the expression of inwardly rectifying potassium channels in polycistronic adenoviral vectors. Infection of superior cervical ganglion neurons did not affect normal electrical activity but suppressed excitability after the induction of gene expression. These experiments demonstrate the feasibility of controlled ion channel expression after somatic gene transfer into neurons and serve as the prototype for a novel generalizable approach to modulate excitability.

Key words: genetic; neuronal excitability; viral gene transfer; inducible expression; gene therapy; adenovirus
Excessive cellular excitability underlies a variety of common, often lethal diseases, ranging from epilepsy to cardiac ventricular arrhythmias. Conventional therapeutic efforts to suppress excitability in such disorders center around the pharmacological block of selected ion channels, mechanical disruption of an irritable focus, or devices such as pacemakers or defibrillators. The drug block of ion channels, although sometimes effective, is plagued by side effects attributable to the systemic administration of drugs needed only in small areas of the body (Jallon, 1997; Loscher, 1998). Mechanical disruption of epileptic or arrhythmic foci is traumatic, irreversible, and often ineffective. Implantable devices designed to terminate hyperexcitation are expensive and are activated only after the seizure has begun. We have explored inducible genetic suppression as an alternative approach to the treatment and prevention of hyperexcitability. Overexpression of inwardly rectifying potassium channel genes driven by an inducible promoter inhibits evoked and spontaneous activity in cultured neurons. Blocking the expressed channels reverses the suppression of excitability. The findings demonstrate that induction of exogenous hyperpolarizing genes effectively suppresses excitability. The inducible expression of such genes represents a new therapeutic principle for use in disorders of hyperexcitability and provides a powerful research tool for probing the contributions of specific regions of the nervous system to the global functional response.

\section{MATERIALS AND METHODS}

Plasmid vectors. The coding sequence for the human Kir2.1 gene was amplified using the PCR to allow in-frame fusion to enhanced green fluorescent protein (EGFP) in the vector pEGFP-C3 (Clontech, Palo Alto, CA) to create pEGFP-Kir2.1. Kir2.1 was also cloned into the vector pGFP-IRES (Johns et al., 1997) to create the vector pGFP-IRESKir2.1. The adenovirus shuttle vector pAdLox (Hardy et al., 1997) was

\footnotetext{
Received Sept. 18, 1998; revised Nov. 19, 1998; accepted Dec. 9, 1998.

Dedicated to the memory of Sir Alan Hodgkin.

This study was supported by Tanabe Seiyaku Company and by National Institutes of Health Grant DA-00266. We thank Dr. S. Hardy for the Cre-lox adenoviral vectors and for helpful discussions.

Correspondence should be addressed to Dr. Eduardo Marbán, Section of Molecular and Cellular Cardiology, 844 Ross Building, The Johns Hopkins University School of Medicine, 720 North Rutland Avenue, Baltimore, MD 21205.

Copyright (C) 1999 Society for Neuroscience $0270-6474 / 99 / 191691-07 \$ 05.00 / 0$
}

modified to replace the cytomegalovirus (CMV) promoter with the ecdysone-inducible promoter from pIND-1 (Invitrogen, San Diego, CA), making the vector pAdEcd. The expression cassettes from pGFP-IRES, pGFP-IRES-Kir2.1, and pEGFP-Kir2.1 were cloned into the multiple cloning site of pAdEcd, making the vectors pAdEGI, pAdEGI-Kir2.1, and $\mathrm{pAdEG}-\mathrm{Kir}$.1. The plasmid pAdVgRXR was made by cloning the expression cassettes from pVgRXR (Invitrogen, San Diego, CA) into pAdLox, encoding the ecdysone receptor.

Cell culture. A549, 293, and CRE8 cells (CCL-185 and CRL-1573; American Type Culture Collection, Rockville, MD; Hardy et al. (1997), respectively) were grown in DMEM (CellGro; Mediatech, Washington, DC) supplemented with $10 \%$ fetal bovine serum (FBS), 2 mm glutamax $1 \times$ penicillin-streptomycin, and 15 mM HEPES, pH 7.4 (Life Technologies, Gaithersburg, MD), at $37 \mathrm{C}^{\circ}$ in a $5 \% \mathrm{CO}_{2}$, humidified incubator.

Viral vectors. Recombinant adenovirus vectors were generated by Crelox recombination (Hardy et al., 1997). A $25 \mathrm{~cm}^{2}$ flask (T25; Sarstedt, Newton, NC) of CRE8 cells was cotransfected with $2.1 \mu \mathrm{g}$ of purified $\Psi 5$ viral DNA and $2.1 \mu \mathrm{g}$ of purified shuttle vector DNA using Lipofectamine Plus (Life Technologies). Cells were incubated 5-9 d until cytopathic effects (CPE) were observed. Cells and media were transferred to a $50 \mathrm{ml}$ polypropylene tube (Sarstedt) and freeze-thawed in a dry ice-ethanol bath and a shaking $37 \mathrm{C}^{\circ}$ water bath. Cells and debris were removed by centrifugation in a clinical centrifuge, and $2 \mathrm{ml}$ of the supernatant was added to a $90 \%$ confluent T25 and returned to the incubator until CPEs were observed. This procedure was repeated three to four times at which time the virus was analyzed for purity by plaque assays. Viruses were then expanded, and large-scale virus purifications were performed as described previously (Johns et al., 1995). Virus titers were determined by plaque assays, and particle numbers were determined by absorbance at $260 \mathrm{~nm}$ on a DU640 spectrophotometer (Beckman Instruments, Fullerton, CA). As has been reported previously (Mittereder et al., 1996), the particle number exceeded the infective particle number by between 40- and 100-fold. Multiplicities of infection (mois) were calculated on the basis of the number of plaque-forming units per milliliter.

Neuronal cultures. Superior cervical ganglion (SCG) neurons were prepared by enzymatic dissociation from ganglia taken from newborn rat pups (Marek and Mains, 1989). Neurons were plated onto glass coverslips coated with rat tail collagen (Bornstein, 1958). Neurons were grown in DMEM/F12 containing 10\% FBS and were treated with $10 \mu \mathrm{M}$ cytosine arabinoside starting $24 \mathrm{hr}$ after plating. Culture media contained $\beta$-nerve growth factor at $100 \mathrm{ng} / \mathrm{ml}$ (Boehringer Mannheim, Indianapolis, IN, or kindly supplied by Dr. David Ginty, Johns Hopkins University, Baltimore, MD).

Infections. Cells (A549 or primary SCG neurons) were infected by replacing their normal growth media with DMEM with 2\% FBS and the appropriate amount of virus for 2-4 hr. The amount of virus used for A549 cells was varied as described for each experiment, whereas the 
amount of virus used for SCG neurons was held constant at $\sim 50$ moi of the test virus and 5 moi of the receptor virus. Infection medium was then replaced with normal growth medium. Expression was induced by addition of muristerone A $[1 \mu \mathrm{M}$ (see Fig. $1 B$ ) and $3 \mu \mathrm{M}$ in all other experiments; Invitrogen] for $22 \mathrm{hr}$ (A549 cells) or $48 \mathrm{hr}$ (SCG neurons) before assays were performed. The dose of muristerone A was selected to activate the receptor maximally on the basis of previously reported dose-response curves (No et al., 1996), which agreed with our own preliminary dose-response curves (data not shown).

Immunohistochemistry. Infected SCG neurons were fixed and stained as described previously (Paquet et al., 1996; Marx and Mains, 1997; Milgram et al., 1997).

Confocal microscopy. Images were taken on a laser-scanning confocal microscope (PCM 2000; Nikon, Melville, NY; excitation, 488 nm; emission, $505-530 \mathrm{~nm}$ ) with a $60 \times$ objective lens (numerical aperture, 1.2).

Electrophysiology. Experiments were performed at $21-23^{\circ} \mathrm{C}$. Wholecell currents were recorded with an Axopatch 1-D amplifier (Axon Instruments, Foster City, CA) sampled at $10 \mathrm{kHz}$ and filtered at $1-5 \mathrm{kHz}$. The pipette solution contained (in $\mathrm{mm}$ ): $140 \mathrm{~K}$-glutamate, $1 \mathrm{MgCl}_{2}, 4$ EGTA, $4 \mathrm{MgATP}$, and $10 \mathrm{HEPES}, \mathrm{pH}$ 7.2. The bath solution for neurons contained (in $\mathrm{mM}$ ): $140 \mathrm{NaCl}, 5.4 \mathrm{KCl}, 2 \mathrm{CaCl}_{2}, 1 \mathrm{MgCl}_{2}, 10$ glucose, and $10 \mathrm{HEPES}$, pH 7.4; for A549 cells, $140 \mathrm{KCl}$ was substituted for $\mathrm{NaCl}$.

Statistics. Pooled data are shown as means \pm SEM. Data were analyzed using two-factor ANOVA. Between-group comparisons were made post hoc with the Fisher's least-significant-difference test.

Flow cytometry. Single-color flow cytometry was used to determine the mean fluorescence intensity of infected A549 cells. Cells were induced $1 \mathrm{~d}$ after infection; $22 \mathrm{hr}$ later, cells were trypsinized, washed, and resuspended in $0.5 \mathrm{ml}$ of PBS. Cells were analyzed on a FacStar (Becton Dickinson, Cockeysville, MD) using forward and side scatter gates to exclude dead cells and cell fragments and collecting $1 \times 10^{4}$ events per sample.

\section{RESULTS}

\section{Inducible viral constructs}

To achieve sensitive control of gene expression after somatic gene transfer, we created adenoviruses that enabled ecdysoneinducible expression of ion channels (No et al., 1996) and reporter genes in mono- or polycistronic vectors (Fig. $1 A$ ). The polycistronic vector, as shown, results in an $\sim 3: 1$ ratio of green fluorescent protein (GFP) to ion channel protein (Dirks et al., 1993), allowing sensitive detection of cells without undue overexpression of the ion channel. Infection of A549 cells with a stoichiometric ratio of 10 ecdysone-driven reporter viruses (AdEGI) per ecdysone/retinoid $\mathrm{X}$ receptor virus (AdVgRXR) produced low basal levels of expression of GFP but $>15$-fold enhancement after addition of the ecdysone analog muristerone A (Fig. 1B). Excess levels of receptor virus lead to higher levels of basal (noninduced) expression (Fig. 1B) as well as a slight decrease in the fold induction achievable. This decrease in the level of induction may be in part attributable to a higher percentage of induced cells above the saturation level of the flow cytometer. The absolute level of expression was increased with increasing levels of the receptor. Removal and readdition of muristerone A (Fig. 1C) could turn expression off and then on again, respectively. To test for inducibility with channel-containing constructs, we coinfected A549 cells with an adenovirus that expresses both GFP and Kir2.1 (AdEGI-Kir2.1; moi = 5) and AdVgRXR (moi = 0.5). When induced, 80-90\% of the cells were GFP-positive in contrast to $<1 \%$ of infected but noninduced cells (based on flow cytometry measurements; data not shown). Membrane current recordings from infected but noninduced cells showed no inwardly rectifying current, whereas induced cells expressing GFP exhibited robust inwardly rectifying currents (Fig. 1D). Overexpression of such channels under physiological conditions in neurons would be predicted to hyperpolarize cells and to suppress excitability.

\section{Infection of neuronal cells}

To confirm efficient infection and inducibility in excitable cells, we used neurons cultured from neonatal rat SCGs. SCG neurons have been used extensively for studies of electrophysiology, biochemistry, and development (Argiro and Johnson, 1982; Nerbonne and Gurney, 1989; Garyantes and Regehr, 1992; McFarlane and Cooper, 1992; Lockhart et al., 1997); in addition, these neurons are known to be amenable to adenoviral gene transfer (Paquet et al., 1996). SCG neurons infected with AdEGI-Kir2.1 and AdVgRXR for $48 \mathrm{hr}$ and treated with vehicle for $22 \mathrm{hr}$ exhibited negligible GFP fluorescence (Fig. $2 A$ ), in contrast with cells imaged $22 \mathrm{hr}$ after the addition of muristerone A (Fig. 2B). A vector containing a GFP-Kir2.1 fusion protein (AdEG-Kir2.1) enabled us to track the distribution of the expressed channel complex. Comparison of the distribution of GFP (Fig. 2D) with that of microtubule-associated protein 2 (MAP2; Fig. 2C) showed substantial overlap (Fig. $2 E$ ); indeed, Kir2.1 protein was distributed throughout the surface and internal membranes of the neurons. In these experiments, $52 \%$ of the MAP2-positive cells were also GFP positive $(n=100)$; in addition, all of the glial cells that could be identified by visible light were GFP positive.

\section{Suppression of neuronal excitability}

In the process of characterizing the phenotypic consequences of Kir2.1 gene transfer and induction, we first compared action potentials and membrane currents in AdEGI-infected and uninfected SCG neurons and found no differences; data from these two groups were thus combined as "control cells" (data not shown). Barium $\left(\mathrm{Ba}^{2+}\right)$ selectively blocks inwardly rectifying potassium channels, which are relatively sparse in control SCG neurons (Wang and McKinnon, 1995). Stimulated action potentials in a control cell were identical in the absence or presence of $\mathrm{Ba}^{2+}$ (Fig. 3A,B), as were membrane currents (Fig. 3C). In contrast, neurons expressing Kir2.1 exhibited diminished excitability. Inward current injection produced only a subthreshold depolarization in an induced cell infected with AdEGI-Kir2.1 (Fig. $3 D$ ); after the addition of $50 \mu \mathrm{M} \mathrm{Ba}^{2+}$, the resting potential depolarized, and a current stimulus of the same intensity evoked a full action potential (Fig. $3 E$ ). The current-voltage relations in this cell reveal marked inward rectification at baseline; the addition of $\mathrm{Ba}^{2+}$ made the membrane currents indistinguishable from those in control cells (Fig. $3 F$ ). In addition to reshaping evoked activity, induced Kir2.1 gene expression also suppressed spontaneous electrical activity (Fig. $3 G-I$ ). Six of 14 control cells exhibited spontaneous activity in normal solution, but none of the 14 induced Kir2.1-infected cells did so. Nevertheless, 5 of these 14 neurons began firing spontaneously after superfusion with $50 \mu \mathrm{M}$ $\mathrm{Ba}^{2+}$. The cell shown in Figure 3, G-I, expressed only $100 \mathrm{pA}$ of $\mathrm{Ba}^{2+}$-sensitive current at $-120 \mathrm{mV}$, revealing that the amount of expression needed to achieve biologically relevant suppression was small. On the other hand, cells with as much as $1.1 \mathrm{nA}$ of current also exhibited $\mathrm{Ba}^{2+}$-induced spontaneous activity, indicating that high-level expression did not irreversibly inhibit the ability of the neuron to respond to normal synaptic input.

Figure 4 summarizes the changes in resting membrane potential $(A)$ and stimulus threshold $(B)$ effected by induction of Kir2.1 expression. In the absence of $\mathrm{Ba}^{2+}$, control cells were depolarized relative to Kir2.1-induced cells ( $-63 \mathrm{vs}-85 \mathrm{mV} ; p<$ 0.0001). Some (but not all) of the control cells exhibited a small depolarization in response to $\mathrm{Ba}^{2+}$, presumably because of the block of low-density native inward rectifiers. In contrast, every Kir2.1-induced cell depolarized after exposure to $\mathrm{Ba}^{2+}(p<$ 
A.

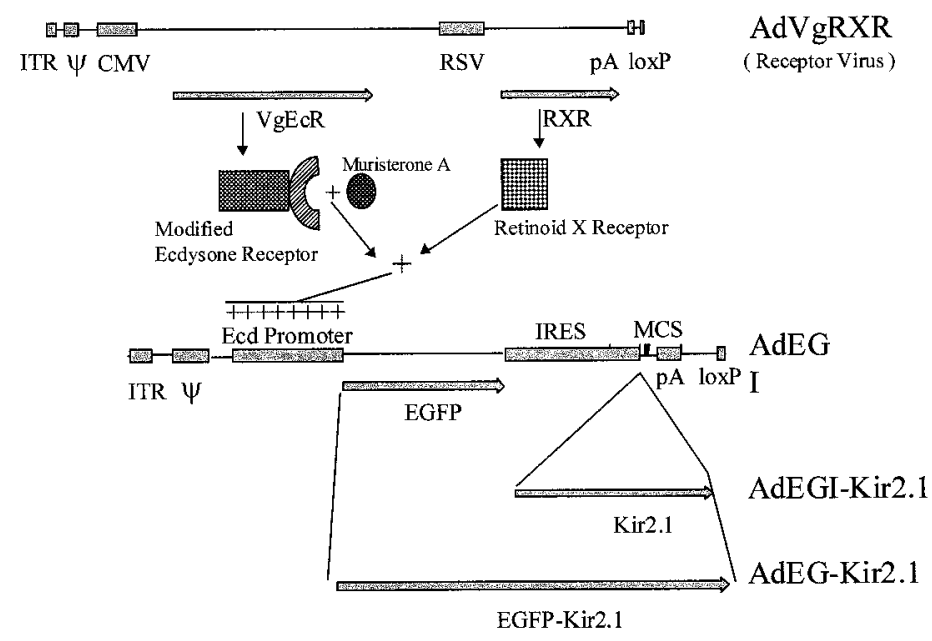

C.

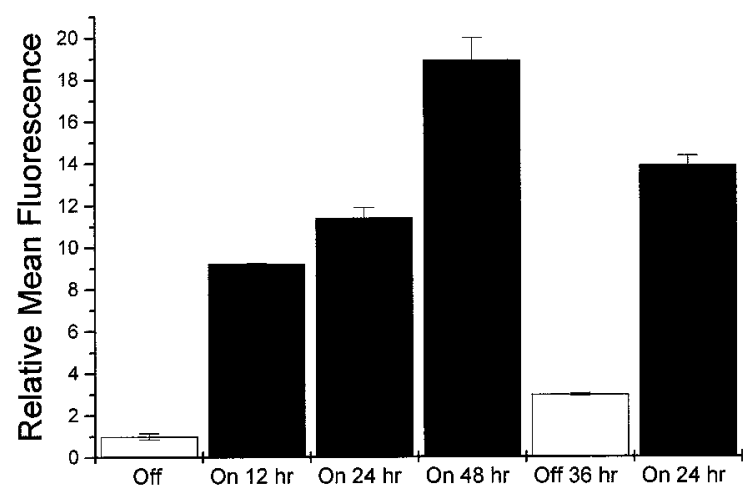

Time Course of Induction and Re-induction
B.

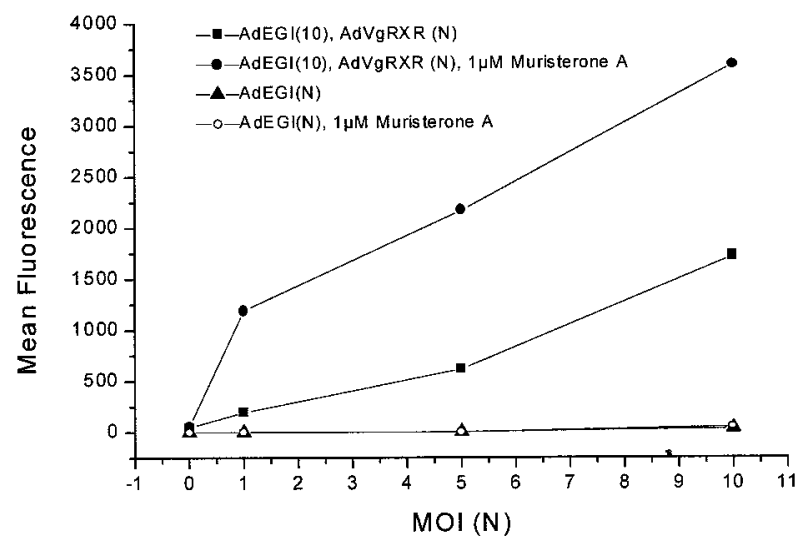

D.

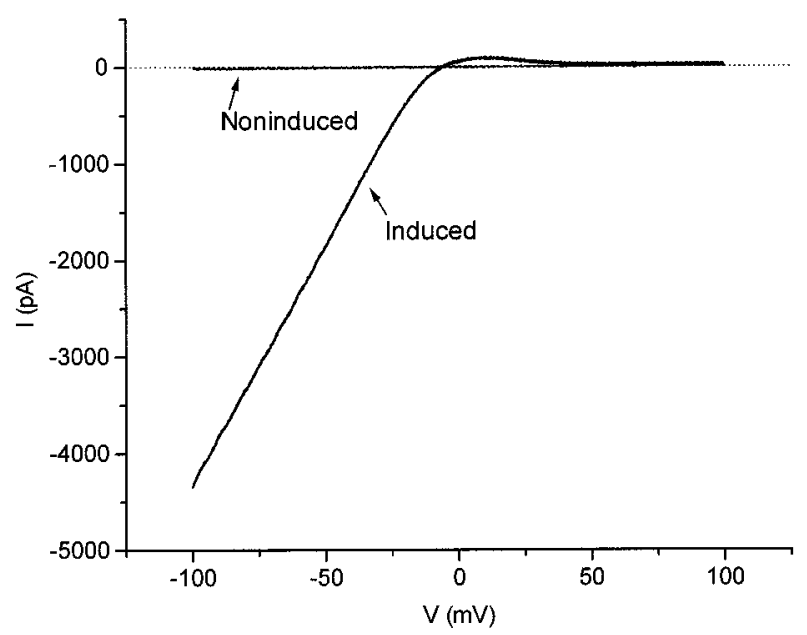

Figure 1. Ecdysone-inducible adenovirus constructs allow tight control of gene expression. $A$, Schematic representation of the basis for the ecdysoneinducible adenovirus vectors is shown. $\psi$, Packaging signal; Ecd promoter, ecdysone-inducible promoter; IRES, internal ribosome entry site; ITR, inverted terminal repeat; $M C S$, multiple cloning site; $p A$, SV40 polyadenylation signal; $R S V$, Rous sarcoma virus; $R X R$, retinoid X receptor; $V g E c R$, modified ecdysone receptor. $B$, Infection of A549 cells with variable mois of both an adenovirus that contains an ecdysone-inducible promoter controlling expression of a cassette containing GFP, an IRES, and a multiple cloning site (AdEGI) and an adenovirus that expresses the modified ecdysone receptor and the retinoid X receptor (AdVgRXR) resulted in muristerone A-dependent and -inducible expression of GFP ( $\boldsymbol{\square}$ vs $\boldsymbol{\bullet}$ ). In the absence of AdVgRXR, background expression was minimal $(\boldsymbol{\Delta})$, and such cells were entirely refractory to muristerone A $(\bigcirc)$. $C$, Expression of GFP in A549 cells, infected with both AdVgRXR and AdEGI, can be induced with $3 \mu \mathrm{M}$ muristerone A for the indicated amounts of time (columns 2-4), reduced to near background levels by the removal of muristerone A for $36 \mathrm{hr}$ (column 5), and reinduced to the original induction level with muristerone A for 24 hr (column 6). D, Membrane currents from A549 cells infected with AdVgRXR and AdEGI-Kir2.1 in the absence $(I=-5 \mathrm{pA} / \mathrm{pF} ; n=2)$ and presence $(I=-80 \pm 12 \mathrm{pA} / \mathrm{pF} ; n=4)$ of $3 \mu \mathrm{M}$ muristerone A are shown.

0.001). Figure $4 B$ quantifies the change in excitability as the difference between the threshold amount of stimulus current needed to fire an action potential in the absence or presence of 50 $\mu \mathrm{M} \mathrm{Ba}^{2+}$. The stimulus threshold was $\mathrm{Ba}^{2+}$ insensitive in control cells. In general, Kir2.1-induced cells required dramatically greater stimuli to reach threshold in the absence of $\mathrm{Ba}^{2+}(p<$ $0.0005)$. To examine the effects of the varying densities of expressed Kir2.1, we divided the cells into two groups based on the amount of $\mathrm{Ba}^{2+}$-sensitive current they exhibited (600 pA was the midpoint; range, 100-1100 pA). The increase in stimulus threshold was distinctly greater in the cells that expressed a higher density of Kir2.1.

\section{DISCUSSION}

Our results demonstrate the ability to modify neuronal excitability genetically in an inducible and reversible manner. The ecdysone regulatory system has little background activity when appropriate amounts of receptor virus are used and yet is inducible to high levels. Under the conditions described, there was an inherently high level of variability of expression among infected cells. This was the result of coinfecting with less than saturating amounts of both the therapeutic virus and the receptor virus. Figure $1 B$ shows that increasing the number of the receptor viruses per cell, while holding the number of test viruses constant, increases the amount of expression. Similar experiments varying 

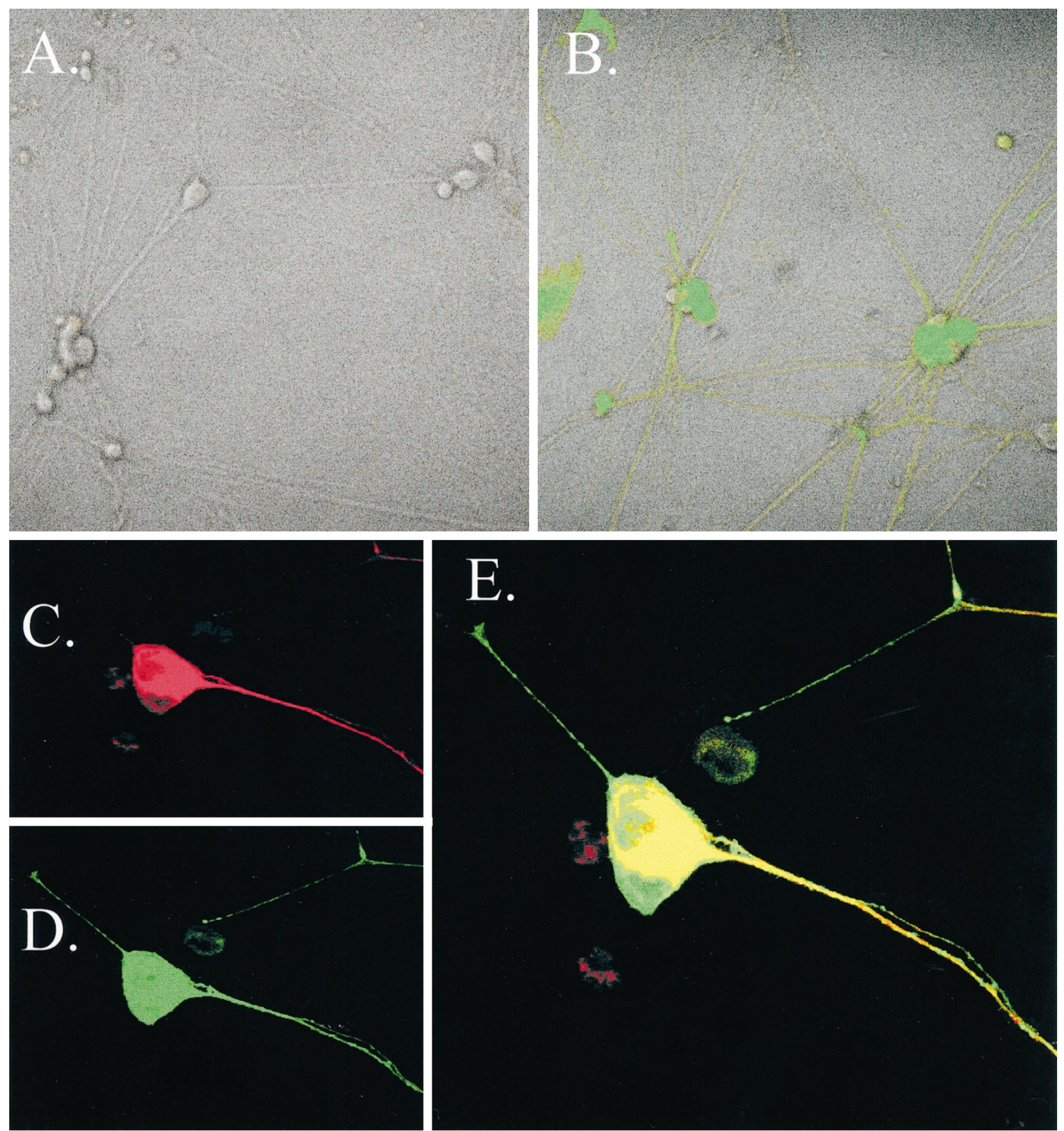

Figure 2. Infection of SCG neurons with inducible adenovirus constructs. $A, B$, Confocal images of SCG neurons infected with AdEGI-Kir2.1 and $\mathrm{AdVgRXR}$ in the absence $(A)$ or presence $(B)$ of muristerone A. $C-E$, A neuron expressing the fusion protein EGFP-Kir2.1 after fixation and staining with a polyclonal antibody to GFP and a monoclonal antibody against the MAP2. An FITC-labeled goat anti-rabbit secondary antibody was used to detect the presence of GFP $(D)$, and a Cy3-conjugated secondary antibody was used to detect the bound anti-MAP2 (C). MAP2 is normally distributed in the dendrites and cell bodies.

the number of test viruses delivered, while holding the number of receptor virus constant, showed that this also affected expression levels (data not shown). The variable levels of GFP fluorescence visible in infected cells confirmed these predictions. For these reasons we did not perform dose-response experiments in neurons, in which the level of muristerone A was also varied. One potential refinement would be to include the receptor complex on the same vector, perhaps under the control of a tissue-specific 
A.

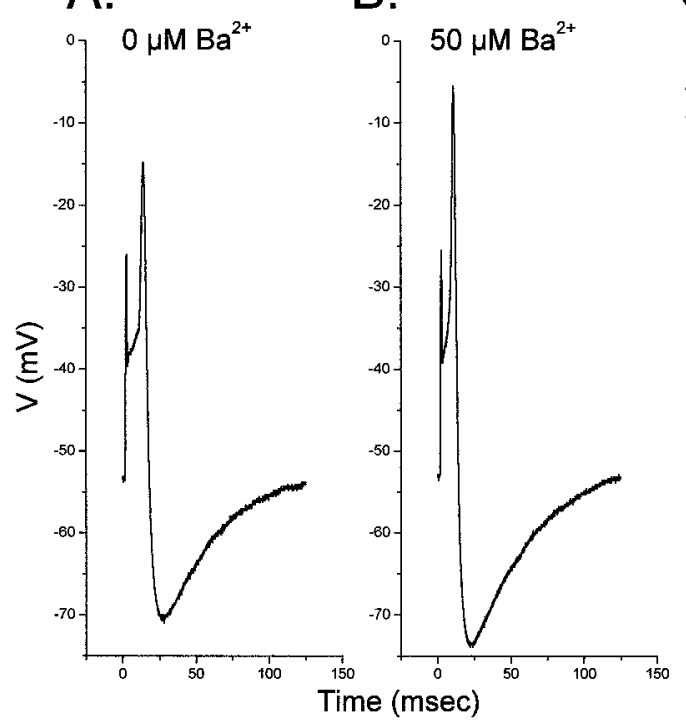

D.

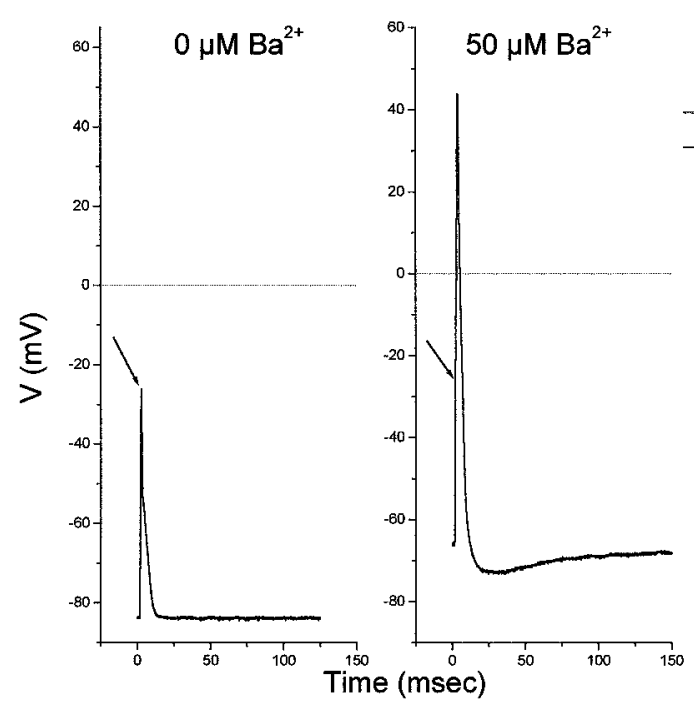

G.

B.

E.

H.

$\mathrm{omV} \rightarrow$

$10 \mathrm{mV}$

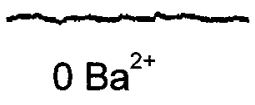

C.

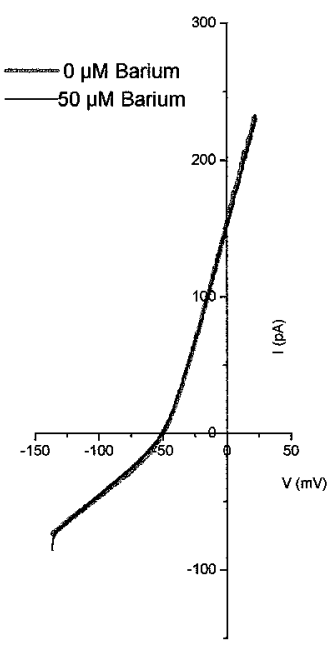

F.

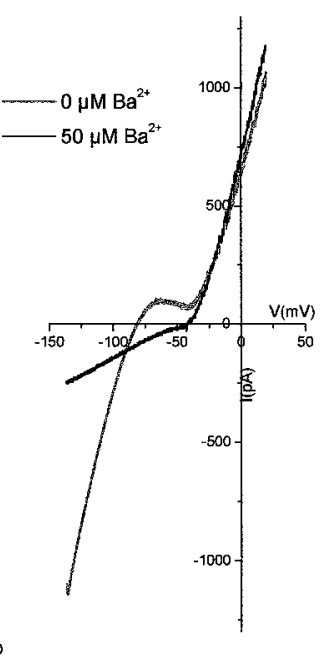

I.

Figure 3. Exogenous expression of Kir2.1 suppresses excitability. $A, B$, The effects of a suprathreshold stimulus on a control cell do not change with the addition of barium. $C$, The membrane current recorded from the same cell under these conditions using a ramp protocol from -138 to +22 $\mathrm{mV}$ over $500 \mathrm{msec}$ is shown. The addition of barium had little or no detectable effect on the outwardly rectifying $I-V$ curves in control cells. $D, E$, The response to a subthreshold stimulus on a Kir2.1-infected cell $(D)$ is markedly changed by the addition of barium $(E)$; the arrow indicates the cessation of the applied stimulus. $F$, The $I-V$ curve for this cell is much different after addition of barium. $G-I$, Membrane current recordings from a Kir2.1-infected cell are shown in normal saline $(G)$, after superfusion with saline containing barium $(H)$, and after washout $(I)$. 
A Control Cells

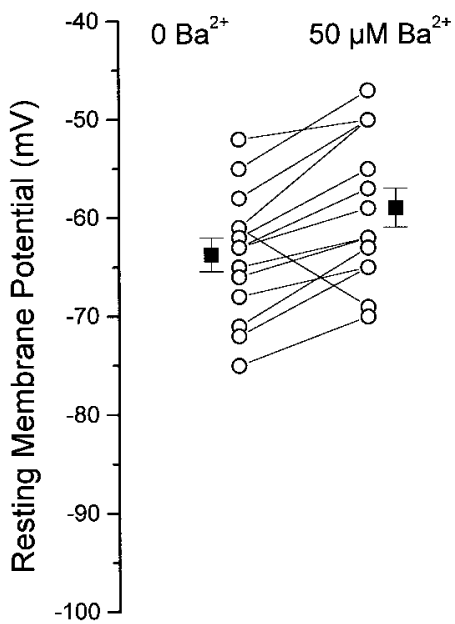

Kir2.1 Cells

B.

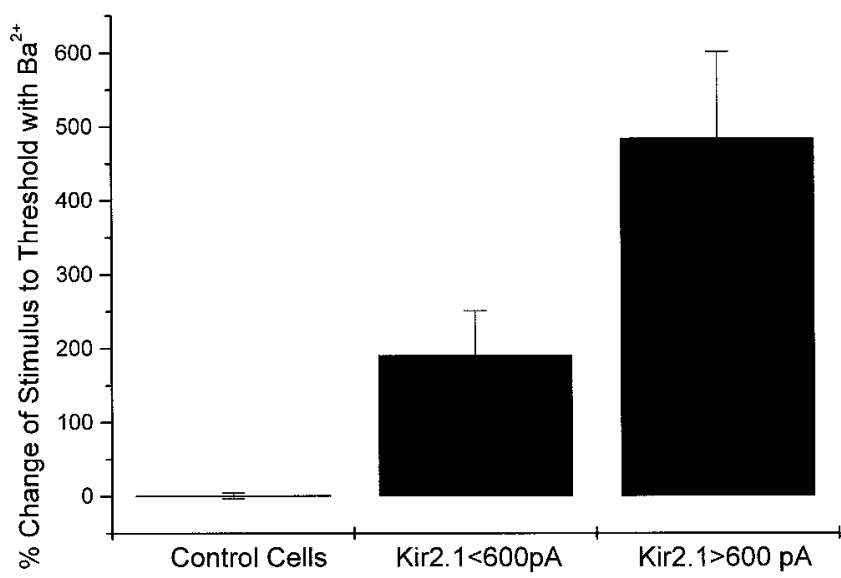

Figure 4. Cumulative effects of exogenous expression of Kir2.1. A, Cells expressing Kir2.1 are hyperpolarized with respect to control cells. This effect is reversed after blocking the Kir2.1 channels. $B$, Increasing amounts of Kir2.1 current increase the size of the stimulus needed to fire an action potential.

promoter, to accomplish more uniform tissue-specific expression. The use of the IRES was quite beneficial in allowing easy detection of positive cells without having to increase the amount of ion channel expression to levels that are not physiologically relevant. These properties enabled us to examine a wide range of electrophysiological effects. On one end, low levels of expression of Kir2.1 sufficed to inhibit spontaneous activity (Fig. 3G-I) despite a relatively modest $66 \%$ increase in the current needed to reach threshold. At the other extreme, two cells, which were not included in the analysis, exhibited $\mathrm{Ba}^{2+}$-sensitive currents $>1.5 \mathrm{nA}$. In these two cells, action potentials could not be elicited when a maximal current stimulus ( $2 \mathrm{nA}$ ) was applied for up to $50 \mathrm{msec}$; nevertheless, in the presence of $\mathrm{Ba}^{2+}$, both of these neurons fired action potentials with modest stimuli. Such stimulus currents far exceed the probable summed inputs for any single neuron and thus represent a complete silencing of electrical activity.

The higher infection efficiency of the glial cell population $(100 \%)$ versus the neuronal population $(52 \%)$ has been observed previously by us as well as others (Moriyoshi et al., 1996; Johns et al., 1997). This represents another potential limitation of this system, in that there may indeed be profound effects of hyperpolarizing the supporting cell population. To avoid this complication in vivo, several strategies could be used. These include the previously mentioned use of neuronal-specific promoters, of vectors modified to increase neuronal tropism (Douglas et al., 1996; Rogers et al., 1997; Dmitriev et al., 1998), or of vectors that are naturally more neurotropic (Douglas et al., 1996; Rogers et al., 1997; Dmitriev et al., 1998).

The potential applications for this technology are widespread. The role of ion channels in nervous system development has been explored previously by the use of blocking reagents (Kater and Mills, 1991; Rakic and Komuro, 1995). Using this strategy may enable genetic manipulation of excitability at different points in development and potentially in specific regions of the CNS. From a clinical standpoint, this targeted and controllable delivery of ion channels may form the basis for new treatments of diseases of excitability such as epilepsy (Wasterlain et al., 1996). In addition, targeted delivery of these (or similar) vectors (Liu et al., 1997) would result in controllable suppression of excitability with the potential for genetic analgesia in the treatment of intractable pain. The ability to turn gene expression on and off at will enables the titration of responses while preserving remarkable safety; if therapy should prove detrimental or ineffective, the inducing agent could simply be withdrawn.

\section{REFERENCES}

Argiro V, Johnson MI (1982) Patterns and kinetics of neurite extension from sympathetic neurons in culture are age dependent. J Neurosci 2:503-512.

Bornstein MB (1958) Reconstituted rat-tail collagen used as a substrate for tissue cultures on coverslips in Maximow slides and roller tubes. Lab Invest 7:134-137.

Dirks W, Wirth M, Hauser H (1993) Dicistronic transcription units for gene expression in mammalian cells. Gene 128:247-249.

Dmitriev I, Krasnykh V, Miller CR, Wang M, Kashentseva E, Mikheeva G, Belousova N, Curiel DT (1998) An adenovirus vector with genetically modified fibers demonstrates expanded tropism via utilization of a coxsackievirus and adenovirus receptor-independent cell entry mechanism. J Virol 72:9706-9713.

Douglas JT, Rogers BE, Rosenfeld ME, Michael SI, Feng M, Curiel DT (1996) Targeted gene delivery by tropism-modified adenoviral vectors. Nat Biotechnol 14:1574-1578.

Garyantes TK, Regehr WG (1992) Electrical activity increases growth cone calcium but fails to inhibit neurite outgrowth from rat sympathetic neurons. J Neurosci 12:96-103.

Hardy S, Kitamura M, Harris-Stansil T, Dai Y, Phipps ML (1997) Construction of adenovirus vectors through Cre-lox recombination. J Virol 71:1842-1849.

Jallon P (1997) The problem of intractability: the continuing need for new medical therapies in epilepsy. Epilepsia 38[Suppl 9]:S37-S42.

Johns DC, Nuss HB, Chiamvimonvat N, Ramza BM, Marban E, Lawrence JH (1995) Adenovirus-mediated expression of a voltage-gated potassium channel in vitro (rat cardiac myocytes) and in vivo (rat liver). J Clin Invest 95:1152-1158.

Johns DC, Nuss HB, Marban E (1997) Suppression of neuronal and cardiac transient outward currents by viral gene transfer of dominantnegative Kv4.2 constructs. J Biol Chem 272:31598-31603.

Kater SB, Mills LR (1991) Regulation of growth cone behavior by calcium. J Neurosci 11:891-899.

Liu Y, Himes BT, Moul J, Huang W, Chow SY, Tessler A, Fischer I (1997) Application of recombinant adenovirus for in vivo gene delivery to spinal cord. Brain Res 768:19-29.

Lockhart ST, Turrigiano GG, Birren SJ (1997) Nerve growth factor modulates synaptic transmission between sympathetic neurons and cardiac myocytes. J Neurosci 17:9573-9582. 
Loscher W (1998) New visions in the pharmacology of anticonvulsion. Eur J Pharmacol 342:1-13.

Marek KL, Mains RE (1989) Biosynthesis, development, and regulation of neuropeptide $\mathrm{Y}$ in superior cervical ganglion culture. J Neurochem 52:1807-1816.

Marx R, Mains RE (1997) Adenovirally encoded prohormone convertase-1 functions in atrial myocyte large dense core vesicles. Endocrinology 138:5108-5118.

McFarlane S, Cooper E (1992) Postnatal development of voltagegated $\mathrm{K}$ currents on rat sympathetic neurons. J Neurophysiol 67:1291-1300.

Milgram SL, Kho ST, Martin GV, Mains RE, Eipper BA (1997) Localization of integral membrane peptidylglycine alpha-amidating monooxygenase in neuroendocrine cells. J Cell Sci 110:695-706.

Mittereder N, March KL, Trapnell BC (1996) Evaluation of the concentration and bioactivity of adenovirus vectors for gene therapy. J Virol 70:7498-7509.

Moriyoshi K, Richards LJ, Akazawa C, O’Leary DDM, Nakanishi S (1996) Labeling of neural cells using adenoviral gene transfer of membrane-targeted GFP. Neuron 16:255-260.

Nerbonne JM, Gurney AM (1989) Development of excitable mem- brane properties in mammalian sympathetic neurons. J Neurosci 9:3272-3286.

No D, Yao T-P, Evans RM (1996) Ecdysone-inducible gene expression in mammalian cells and transgenic mice. Proc Natl Acad Sci USA 93:3346-3351.

Paquet L, Massie B, Mains RE (1996) Proneuropeptide Y processing in large dense-core vesicles: manipulation of prohormone convertase expression in sympathetic neurons using adenoviruses. J Neurosci 16: 964-973.

Rakic P, Komuro H (1995) The role of receptor/channel activity in neuronal cell migration. J Neurobiol 26:299-315.

Rogers BE, Douglas JT, Ahlem C, Buchsbaum DJ, Frincke J, Curiel DT (1997) Use of a novel cross-linking method to modify adenovirus tropism. Gene Ther 4:1387-1392.

Wang HS, McKinnon D (1995) Potassium currents in rat prevertebral and paravertebral sympathetic neurones: control of firing properties. J Physiol (Lond) 485:319-335.

Wasterlain CG, Shirasaka Y, Mazarati AM, Spigelman I (1996) Chronic epilepsy with damage restricted to the hippocampus: possible mechanisms. Epilepsy Res 26:255-265. 